\title{
KRITIK PEMAHAMAN HADIITH NEGARA ISLAM IRAK DAN SURIAH (NIIS)
}

\author{
Muhammad Najih Arromadloni \\ Universitas Islam Negeri Sunan Ampel Surabaya, Indonesia \\ E-mail: najika.99@gmail.com
}

\begin{abstract}
The politization of hadith within social and political dimension has been in fact an undeniable matter since the beginning of the Islamic history. The proponents of Negara Islam Irak dan Suriah (NIIS) [The Islamic State in Iraq and Syria (ISIS)], as a modern political movement, claim haditth as one of their main religious, social, and political justifications, which is actually incongruous to the mainstream understanding of the global Muslim community. It is, therefore, a necessity to raise a discourse for analyzing the understanding of NIIS's proponents on hadith based on the Method of Critique of Matn or Ma'ânî al-Hadîth. The research focuses mainly on Dabiq magazine which is officially issued by the NIIS. It is analyzed descriptively, critically, and comparatively. The research concludes that the understanding of NIIS's proponents on hadith on kbilâfah, jïhâd, bijrah, imân and almalhamat al-kubrâ has erroneously deviated from the common and approved methods employed by the scholars of hadith. NIIS's understanding has been widely criticized by the scholars of hadith of being partial, inconsistent, less careful, and has no theological, ideological and political root as well as historical evidences.
\end{abstract}

Keywords: Hadîth; understanding; NIIS.

\section{Pendahuluan}

Dalam norma keberagamaan umat Islam, hadîth mempunyai posisi yang menentukan sebagai sumber hukum Islam, di samping al-Qur'ân ${ }^{1}$

1 Lihat detail posisi hadîth atau Sunnah dalam Islam dalam Muḥammad b. Naṣr alMarwazî, al-Sunnab (Beirut: Maktabat al-Dâr, 1406 H.), 68-72. Lihat pula ringkasan peran hadîth terhadap al-Qur'ân dalam Muhammad Ḥusayn al-Dhahabî, al-Tafsîr wa alMufasirûn, Vol. 1 (Mesir: Maktabah Wahbah, 2000), 55-57. Ayat al-Qur'ân yang melegitimasi ḥadîth sebagai sumber sharî‘ah di antaranya: QS. al-Nisâ [4]: 8 dan 59, QS. 
atau sebagai manifestasi al-Qur'ân ${ }^{2}$, bahkan secara hierarkis mempunyai otoritas yang sama dengan al-Qur'ân. ${ }^{3}$ Selaku perangkat teologis, hadîth akan menjadi rujukan bagi umat Islam dalam menjalani kehidupannya di dunia. ${ }^{4}$ Ulama menyepakati pengingkaran terhadap ḥadîth secara umum merupakan bentuk keluar dari agama. Dalam posisi tersebut, hadîth menjadi salah satu sentral konsentrasi umat Islam ${ }^{5}$, dan secara inheren mempunyai nilai politis ${ }^{6}$ yang tinggi.

Nilai politis hadîth dalam sejarah politik umat Islam telah memberikan tarikan magnetik kepada aktor-aktor yang berkepentingan melampaui kaidah periwayatan dan pemahaman hadîth yang telah ditetapkan oleh para ulama dalam melegitimasi propaganda kebijakan masing-masing. ${ }^{7}$

Politisasi hadîth dapat mengejawantah ke dalam berbagai dimensi, dari penegasan identitas parokial sampai usaha merekonstruksi masyarakat atas dasar prinsip-prinsip keislaman. Di dasar tuntutan itu

Al 'Imrân [3]: 31, 32, dan 132, QS. al-Naḥl [16]: 44 dan 64, QS. al-An'am [6]: 163, QS. al-Anfâl [8]: 34, QS. al-Aḥ̂âb [33]: 21 dan 36, dan QS. al-Najm [53]: 3.

${ }^{2}$ Abû al-Ḥusayn Muslim b. al-Hajjâj al-Naysâbûrî, Șaḅ̂h Muslim, Vol. 1 (Beirut: Dâr alFikr, 1993), 331.

3 Ayat al-Qur'ân yang mendukung pernyataan ini adalah QS. al-Hashr [59]: 7. Dalam beberapa hal dasar, hadîth memang berbeda dengan al-Qur'ân. Muhammad 'Ajjâj alKhatîb, Uș̂il al-Ḥadîth 'Ulûmuh wa Muṣtalaḥuh (Beirut: Dâr al-Fikr, 1989), 30.

4 M. M. Azami, Hadis Nabi dan Sejarah Kodifikasinya, terj. Ali Mustafa Yaqub (Jakarta: Pustaka Firdaus, 2009), 27.

5 Muhammad 'Ajjầ al-Khâtî̉b, al-Sunnah Qabl al-Tadwrin (Beirut: Dâr al-Fikr, 1997), 1516.

6 Politis berarti bersangkutan dengan politik. Lihat Ahmad Syafici Ma'arif, Islam dan Masalab Kenegaraan (Jakarta: LP3ES, 1985), 12. Lihat pula Philip Babcodk Gove et. al., Webster Third New International Dictionary of The English Language (Massachusett: G \& C Merriam Company, 1961), 1755.

7 Secara historis, Islam memang mempunyai sejarah pergolakan politik yang panjang, dari sepeninggal Nabi. Sisi politis dalam Islam, sebagaimana dituturkan Nurcholis Madjid, melekat begitu kentalnya sehingga sulit dipisahkan. Islam tumbuh bukan hanya menjadi komunitas spiritual dan kerohanian, melainkan telah menjadi komunitas atau society yang kuat. Pada aspek totalitasnya sebagai kerumunan masyarakat atau komunitas politik inilah, Islam selalu dibedakan dengan agama-agama lain semisal Kristen dan Hindu. Kenyataan historis itu, menjadi dasar bagi adanya pandangan yang merata di kalangan para ahli dan awam, baik Muslim maupun non-Muslim, bahwa Islam adalah agama yang terkait erat dengan politik kenegaraan. Lihat Abd. Halim, Relasi Islam Politik dan Kekuasaan (Yogyakarta: LKiS, 2013), 29. 
terdapat isu penerapan manhaj nubuwwah terkadang mengambil bentuk aksi-aksi politik dan mobilisasi dengan menggunakan kekerasan.

Politisasi hadîth atau agama secara umum dan kekhawatiran terhadapnya telah mendorong para akademisi untuk menggelar diskusi, lokakarya, seminar, dan konferensi. Ratusan bahkan ribuan kajian telah diterbitkan yang mengupas berbagai kasus dan beragam aspek Islam politik. Tetapi analisis-analisis yang tersedia umumnya baru sebatas analisis deskriptif tentang sejarah, ideologi, struktur dan tujuan gerakangerakan yang berada dalam spektrum Islam politik. Buah dari analisisanalisis semacam ini kerap kali tak memuaskan dan cenderung mengukuhkan kecurigaan terhadap ajaran-ajaran Islam atau pengalamanpengalaman buruk kesejarahan dunia Islam. Kalaupun pendekatan komparatif digunakan, ia terbatas pada usaha mengomparasikan Islam politik dengan gerakan-gerakan fundamentalisme keagamaan lainnya yang memiliki landasan ideologi dan orientasi serupa. Jarang ada analisis yang menukik tajam dengan menggunakan kerangka teoretik dan konseptual yang mendasar. ${ }^{8}$

"Kertas kerja" ini dihadirkan dengan maksud menutupi celah kelangkaan analisis tersebut dengan menelisik paham ideologi Negara Islam Irak dan Suriah/Islamic State of Iraq and Syria (NIIS/ISIS) menggunakan justifikasi pendekatan ilmu hadîth, yaitu bagaimana pemahaman mereka atas hadîth dan bagaimana tinjauan ulama hadîth atas pemahaman tersebut. Kritik hadîth baik sanad maupun matan di kalangan ahli hadîth akan menjadi topik sentral untuk melihat beragam pemahaman-pemahaman tersebut secara komparatif. Pendekatan ini diharapkan dapat membawa kesegaran dan nuansa-nuansa baru sebagai methodological breakthrough ke dalam diskusi tentang politisasi hadîth, dan agama secara umum sekaligus memberikan sumbangan bagi perkembangan teori pemahaman ḥadîth (ma'ânî al-ḥadîth).

\section{Sejarah dan Landasan Ideologi NIIS}

1. Genealogi NIIS

NIIS (Negara Islam Irak dan Suriah) dalam bahasa Inggris ISIS (Islamic State of Iraq and Syria) dan dalam bahasa Arab Dâiish (al-Dawlah al-

8 Noorhaidi Hasan, "Book Review: Islam Politik Teori Gerakan Sosial dan Pencarian Model Pengkajian Islam Baru Lintas-Disiplin”, al-Jâmi‘ah, Vol. 44, No. 1 (2006 ), 242243. 
Islâmîyah fî al-Irâq wa al-Shâm) mempunyai sejarah yang panjang. Namanya pun telah mengalami beberapa kali pergantian, awalnya bernama Tanz̧în al-Dawlah al-Islâmîyah fî al-Irâq. Setelah berhasil memanfaatkan situasi konflik di Suriah dan menguasai sebagian wilayahnya berganti nama menjadi Tanz̧îm al-Dawlah al-Islâmîyah fî al-'Irâq wa al-Shâm. Pasca-deklarasi resmi menjadi negara, kata tanz̧îm (organisasi) mereka hilangkan, sehingga menjadi al-Dawlah al-Islamîyah fî al-Irâq wa alShâm. Saat ini, setelah berhasil melakukan ekspansi ke luar Irak dan Suriah, mereka berganti nama kembali menjadi al-Dawlah alIslâmîyah/Islamic State/Negara Islam. ${ }^{9}$ Dalam penulisan artikel ini, nama NIIS dan ISIS digunakan dengan pertimbangan popularitas di kalangan masyarakat. ${ }^{10}$

Secara organisasi, cikal-bakal NIIS bisa dilacak sampai ke Jamâ'at alTawhîd wa al-Jihâd yang didirikan pada tahun 2002 oleh Abû Muṣ'ab alZarqâwi ${ }^{11}$, bermula dari lahirnya al-Qaeda Irak (AQI) tahun 2003, pascainvasi AS ke Irak. ${ }^{12}$ Sejarah NIIS bahkan bisa dilacak lebih jauh sampai pada awal tahun 1990-an, yang dimulai oleh alumni Afghanistan di Yordania tersebut.

Pada akhir 1989, al-Zarqâwî meninggalkan negara asalnya menuju Afghanistan yang tengah berperang melawan Uni Soviet, dengan nama baru Abû Muhammad al-Gharîb. ${ }^{13}$ Dia bermukim di Hayatabad sebelum

9 NIIS menggambarkan profilnya sendiri dalam: http://theshamnews.com /?page_id $=60$

10 Secara teknis ISIS sudah tidak eksis. Nama resmi untuk organisasi ini sekarang adalah Islamic State (IS) saja. Dalam penulisan artikel ini tetap digunakan nama ISIS selain karena alasan popularitas juga demi kenyamanan, karena ada debat hangat soal nomenklatur. Akronim Dấish sendiri dianggap prejoratif karena nada keras dalam pelafalannya. Kombinasi huruf-huruf Arab tersebut berkonotasi kekasaran, kekerasan, dan kebodohan. Dalam bahasa Arab, ia bermakna menghancurkan sesuatu dengan menginjaknya atau menabur perselisihan.

11 Joseph Felter dan Brian Fishman, al-Qa'ida's Foreign Fighters in Iraq (New York: Combating Terrorism Center, 2007), 4. ISIS mempunyai tautan rekam jejak dengan berbagai faksi militan, di antaranya adalah Așâib Abl al-Haq, Katấib Hiz̧bullah, Islamic Army of Iraq, dan lain sebagainya. Lihat Reno Muhammad, ISIS Kebiadaban Konspirasi Global (Jakarta: Noura Books, 2014), 23-34.

12 Zana Khasraw Gulmohamad, "The Rise and Fall of The Islamic State of Iraq and alSham (Levant) ISIS”, Global Security Studies, Vol. 5 (Spring, 2014), 2.

13 Loretta Napoleoni, Insurgent Iraq al-Zarqawi and The New Generation (New York: Seven Stories Press, 2005), 42. 
pindah ke Peshawar. Di kota tersebut Osama bin Laden (pendiri alQaeda) dan 'Abd Allah Azzam (ideolog mujahidin Afghanistan) mendirikan Maktab al-Khadamât (Biro Pelayanan) dan menjadi "induk semang" bagi mujahidin asing di kawasan tersebut.

Tahun 1999 ketika al-Zarqâwî pergi ke Pakistan dan menyusup ke Afghanistan, ia bertemu untuk pertama kalinya dengan Osama b. Laden di Kandahar yang dikuasai oleh Taliban. Meski berbeda dalam beberapa hal, keduanya menjalin sebuah kerjasama. Al-Zarqâwî mempunyai relasi yang luas di Suriah dan dianggap bermanfaat untuk al-Qaeda. Salah satu relasi tersebut adalah Abû Muḥammad al-'Adnânî yang kini merupakan juru bicara NIIS.

Melalui pendanaan sejumlah 200.000 USD yang diberikan oleh Osama, al-Zarqâwî membentuk sebuah kamp pelatihan militer di Herat dan anggotanya disebut dengan Jund al-Shâm, jaringannya di Irak bernama al-Tawhîd wa al-Jihâd, dan telah ambil bagian dalam banyak serangan spektakuler seperti rancangan pemboman Ibu Kota Yordania pada 2004. Jaringannya juga dikembangkan di Irak Utara dengan nama Jund al-Islâm. Pasca-serangan 11 September dan diawalinya invasi Amerika Serikat ke Afghanistan, Jund al-Islâm bergabung dengan kelompok lainnya menjadi Anșâr al-Islâm.

Pasca-baiatnya al-Zaqâwî kepada Osama pada Oktober 2004, nama Tawhî̀ wa al-Jihâd diganti menjadi Tanzîm Qâ'edat al-Jihâd fi Balad alRafidain (Organisasi Jihad al-Qaeda di Kawasan Dua Sungai) dan kemudian lebih dikenal dengan al-Qaeda Irak (AQI). Jadi, al-Zarqâwî mulanya hanya menjadi sekutu al-Qaeda, namun setelah dimulainya perang ia sepenuhnya menjadi komandan lapangan untuk Osama. ${ }^{14}$

Al-Zarqâwî terbunuh pada 7 Juni 2006 di tangan tentara Amerika Serikat di Baquba sebelah utara Baghdad ${ }^{15}$, dan Majelis Syuro Mujahidin memindahkan kepemimpinan AQI kepada Abû Ayyûb al-Mașrî yang berkebangsaan Mesir dan mempunyai julukan Abû Hamzah al-Muhâjir. Al-Mașri sudah terlibat dalam kegiatan terorisme sejak 1980-an dan mengenal al-Zawâhirî dan al-Zarqâwî secara personal selama berada di kamp al-Qaeda di Afghanistan dan di Irak.

14 Michael Weiss dan Hassan Hassan, ISIS: The Inside Story, terj. Tri Wibowo BS (Jakarta: Prenada Media, 2015), 39.

15 The $W$ ashington Post, Kamis, 8 Juni 2006. 
Al-Mașri melanjutkan kepemimpinan dengan melakukan beberapa perubahan, di antaranya pada 15 Oktober 2006 tepat di bulan Ramadan $1427 \mathrm{H}$ mendeklarasikan dukungan terhadap gerakan perlawanan yang diberi nama Islamic State of Iraq (Negara Islam Irak) yang wilayah kekuasaannya meliputi provinsi Ninewah, Anbar, dan Șalâh al-Dîn, serta beberapa area seperti Bâbil, Wâsit, Diyalâ, Baghdad, dan Kirkuk. Pemimpin ISI adalah Abû 'Umar al-Baghdâdi, yang pribumi Irak dan dipilih oleh Majelis Syuro Mujâhidîn. Baiat al-Mașrî kepada al-Baghdâdî langsung menempatkan AQI secara hirarkis di bawah ISI.

ISI selanjutnya mengubah agensi Majelis Syuro Mujâhidîn dengan melakukan pola nation building (membangun sebuah negara), yaitu membentuk beberapa kementerian seperti kementerian pertanian, perminyakan dan kesehatan. Kursi-kursi kementerian ini diduduki oleh para ulama, profesional dan akademisi. NIIS juga mempunyai gubernur di masing-masing provinsi yang bertanggung jawab atas administrasi daerah.

Al-Mașrî dan al-Baghdâdi ternyata tidak lama mengomando ISI, karena pada 18 April 2010, operasi JSOC Amerika berhasil menemukan persembunyian keduanya di Tharthar, perbatasan kota Sạlâh al-Dîn dan 'Anbar. Pengganti yang ditunjuk oleh mayoritas (9 dari 11) anggota Majelis Syuro ISI untuk dua komandan yang telah tewas tersebut adalah Ibrâhîm Awwâd Ali al-Badrî al-Samarrai, alias Abû Bakr al-Hâshimî alḤusaynî al-Qurashî al-Baghdâdî, alias Abû al-Du'a, alias Ḥâmed Dawûd Mohammed Kholil al-Zawri, yang mempunyai julukan Abû Bakr alBaghdâdî. ${ }^{16}$ Dia juga digelari oleh pejuang NIIS sebagai Shaykh Syabah yang berarti Shaykh Hantu. ${ }^{17}$

Al-Baghdâdî adalah seorang doktor di bidang studi Islam dengan konsentrasi Studi al-Qur'ân dari Universitas Ilmu Islam di Adhamiya, pinggiran Baghdad. Dia lahir di Samarra pada tahun 1971 dengan nama Ali al-Badri al-Samarrai. Al-Baghdâdî adalah anggota al-Ikhwân alMuslimûn atau afiliasinya. Kecenderungan Salafi-Wahabisnya muncul belakangan, mengikuti Mohammed Hardan, seorang pemimpin alIkhwân al-Muslimûn yang mengadopsi ideologi Wahabi setelah

16 Lauren Gelfand, "al-Qaeda in Iraq Regroups and Names New Leadership", Janes's Defense Weekly, 19 Mei 2010.

${ }^{17}$ Ikhwanul Kiram Mashuri, IS IS Jihad atau Petualangan (Jakarta: Republika, 2014), 26. 
kepulangannya dari Afghanistan tahun 1990-an, dan pendiri Jaysh alMujâhidîn. ${ }^{18}$

Bersamaan dengan masuknya Jabhat al-Nuṣrah ke seluruh Suriah pada Agustus 2013, ISI mulai menguasai Raqqa. Al-Baghdâdî—sembari mengonfirmasi penguasaan tersebut pada 8 April 2013 — mengumumkan bahwa al-Nușrah dan ISI akan bersatu dalam gerakan kombatan lintasregional yang akan membentuk apa yang disebut sebagai Islamic State of Iraq and Syria (ISIS) atau Islamic State of Iraq and Levant (ISIL), atau Negara Islam Irak dan Suriah (NIIS). NIIS berpisah dengan al-Qaeda karena perbedaan prinsipil yang gagal ditengahi oleh Aymân al-Ẓawâhirî, pada 2 Februari 2014, dan pada 10 Juni 2014 ketika menyerbu Mosul, NIIS berhasil menghancurkan dinding pembatas yang memisahkan Irak dan Suriah. Raqqa dan Mosul kemudian menjadi ibukota de facto ISIS.

Pasca-penyerbuan Mosul, al-Baghdâdî mendeklarasikan lahirnya sebuah entitas politik, yaitu kekhalifahan yang baru dengan dirinya sebagai khalifah, dan pada 29 Juni 2016, kata "Irak dan Suriah" dibuang dari Islamic State of Iraq and Syria (ISIS) sehingga menjadi Islamic State (IS) atau Negara Islam (NI) saja. Satu pekan pasca-deklarasi kekhilafahan, yakni 4 Juli 2014, al-Baghdâdî dalam kemunculan perdananya di depan publik, menyerukan agar semua umat Islam di seluruh dunia berbaiat dan taat kepadanya sebagai khalifah yang baru.

\section{Ideologi NIIS}

Kajian atas ideologi yang dianut NIIS sangat singnifikan, mengingat problematikanya ditengarai menjadi salah satu akar faktor kemunculan dan eksistensi NIIS, di samping faktor sosial-politik, psikologi, budaya dan ekonomi. Dalam sub-ideologi, pemahaman dan penggunaan bahasa hadith menemukan relevansinya ${ }^{19}$, meski yang dominan tetaplah permasalahan sosial-politik, baik berupa kesenjangan, ketidakadilan,

\footnotetext{
18 Ibid., 133.

19 Louise Richardson menulis mengenai peran ideologi dalam tindak terorisme, The causes terrorism are not be found in objective conditions of proverty or privation or in ruthless quest for domination but rather in a lethal cocktail that combines a dissafected individual, an enabling community, and a legitimizing ideology. Louise Richardson, What Terrorism Want: Understanding the Terrorist Threat (USA: Random House, 2006), 12.
} 
tindakan semena-mena, pelanggaran hak kemanusiaan, dan tersumbatnya saluran aspirasi terhadap pemegang otoritas. ${ }^{20}$

Akar ideologi NIIS-sebagaimana dinyatakan oleh Fuâd Ibrâhîm ${ }^{21}$ dan Ikhwanul Kiram Mashuri-adalah Salafi-Wahabi ${ }^{22}$ yang berhaluan Jihadi. Kelompok minoritas umat Islam yang selama ini dikenal telah menghalalkan segala cara-termasuk dengan kekerasan dan terordalam perjuangannya. ${ }^{23}$ Salah satu misi utamanya adalah mempurifikasi Islam dari selain al-Qur'ân dan hadîth, termasuk aspek maslahat dan mafsadat, padahal keduanya merupakan bidang inti kaidah fiqh-sharîah. Wahabi juga dikenal gemar menganggap dan menuduh kelompok di luar alirannya tidak sesuai sharî‘ah Islam, menyimpang, bid'ah, musyrik, dan kafir. Ajaran ini telah berkembang ke berbagai negara, termasuk negara minoritas Muslim.

Salafisme atau Wahabisme inilah yang kemudian dapat menjadi lahan subur bagi lahirnya aneka kelompok terorisme dan konflik. Sebab, pola

20 Anshaad Mbai, Dinamika Baru Jejaring Teror di Indonesia (Jakarta: AS Production, 2014), 124-125.

21 Fuâd Ibrâhîm, Dâiish min al-Najdi ilâ al-Baghdâdî (Beirut: al-Markaz al-Awwal li alDirâsât wa al-Tawthîq, 2015).

22 Tanpa bermaksud melakukan simplifikasi atau generalisasi antara ISIS dan Wahabi, faktanya pengaruh pemikiran Wahabi terhadap ISIS akup signifikan. Ini bisa dibuktikan dengan seringnya ISIS menyitir pendapat Muhammad b. 'Abd al-Wahhâb, pendiri Wahabi, sekligus menjadikannya teladan. Lihat misalnya dalam majalah Dabiq, edisi II, Ramadhan 1435 H., 22. ISIS memuji-muji pendiri Wahabi dalam majalah Dabiq, edisi V, Muharam 1436, 26, dan menyebut pendiri negara Arab Saudi yang berideologi Wahabi, Sa'ûd b. 'Abd al-'Azîz, sebagai Pemimpin Para Mujahid, dalam Dabiq, edisi X, Ramadan 1436 H., 59. Bahkan ketika ISIS menaklukan kota Mosul mereka membagikan buku-buku karya Muḥammad b. 'Abd al-Wahhâb atau saat memasuki kota Aleppo. ISIS juga kerap mengutip dan menyadur pemikiran-pemikiran dua tokoh idola pendiri Wahabi, yakni Ibn Taymîyah dan Ibn al-Qayyim al-Jawzîyah.

Banyak kalangan menganggap bahwa ISIS adalah jelmaan baru Khawârij, kelompok Muslim garis keras pertama dalam sejarah. Keduanya mempunyai banyak ciri yang sama, namun ISIS secara resmi menolak tuduhan tersebut, sebagaimana disampaikan oleh juru bicara Abû Muḥammad al-'Adnâni. Lihat Dabiq, edisi II, Ramadhan 1435 H., 20 .

Ciri utama radikalisme ISIS sama dengan Khawârij, yakni lebih berorientasi ke dalam (inward) ketimbang keluar. Dalam hal ini yang menjadi target gerakan ini bukanlah pihak luar (non-Muslim), namun kelompok Islam sendiri yang dianggap telah menyimpang dari Islam, atau memiliki pemahaman Islam yang berbeda dengan mereka.

23 Mashuri, ISIS, 4. Namun sumber lain juga menyebutkan bahwa ISIS merupakan sempalan dari kelompok Syiah radikal. Lihat Mashuri, ISIS, 11. 
ajaran purifikasinya akan mudah digerakkan dengan keyakinan "yang lain salah, sesat, dan kafir". Ajaran-ajaran tersebut merupakan bahasa politik untuk memobilisir umat Islam dalam mendukung kelompok mereka.

Tokoh-tokoh ideologis NIIS adalah 'Abd Allah Azzam yang pada 1984 menulis buku yang menjadi manifesto untuk pengikutnya. ${ }^{24}$ Tokoh lain adalah Ayman al-Ẓawâhirî, pemimpin Jemaah al-Jihad yang pernah terlibat dalam plot pembunuhan Presiden Mesir Anwar Sadat dan berusaha melakukan coup d'etat di Kairo dalam rangka mendirikan negara teokrasi Islam di sana. Dengan konsep takfirisme - mengafirkan sesama Muslim menggunakan tuduhan bidah dan sesat, dan menimbulkan konsekuensi hukum yang hampir selalu berupa hukuman mati. Tokoh NIIS lainnya adalah Abû Muhammad al-Maqdisî yang mempunyai interaksi dengan al-Zarqâwî. Ia sempat mempublikasikan tulisan antiBarat yang radikal yang berjudul Democracy: A Religion. Di dalam karya tersebut ia mendikotomikan secara tegas antara ekonomi dan politik taghât (kafir) dan hukum ilahi (sharî‘ah). Al-Maqdisî menjadi sumber utama otoritas ideologi radikalis Salafi di Yordania. NIIS menggunakan strategi kekerasan yang menakutkan, yang didapatnya dari karya Abû Bakr Nâjî̀, yakni Idârat al-Tawahush ${ }^{25}$ (Manajemen Kekejaman) berisi tentang pedoman lapangan sekaligus manifesto untuk membangun kekhilafahan Islam.

Anggota NIIS terdiri dari ragam latar belakang dan sistem keyakinan, mulai dari para oportunis yang tidak percaya Tuhan, kelompok

\footnotetext{
${ }^{24}$ Weiss dan Hassan, ISIS: The Inside Story, 4. Buku dimaksud berjudul al-Difấ 'an Arâd al-Muslimîn Ahamm Furûd al-'Uyûn, dirilis oleh Minbar al-Tawhị̂d wa al-Jihâd.

Jika diamati lebih dalam, ISIS juga banyak terpengaruh oleh kitab al-Farịdat al-Ghấibah karya 'Abd al-Salâm Faraj. Kitab ini merupakan kitab induk yang menjadi panduan pola pikir organisasi-organisasi jihadis seperti al-Ikhwân al-Muslimûn, al-Qaidah, dan lain sebagainya. Terbit pada tahuan 1981.

25 Judul lengkapnya adalah Idârat al-Tawahush Akhtar Marhalat Satamurr bihâ al-Ummah. Karya ini telah didigitalisasi dalam format PDF oleh Markaz al-Dirâsât wa al-Buhûth alIslâmîyah dan bisa diunduh di situs: https://pietervanostaeyen.files.idarat_altawahhush_-_abu_/02/wordpress.com/2015.bakr_naji.pdf. Penulisnya, Abî Bakr alNâjî̀, diyakini adalah sosok bernama asli Muḥammad Khalîl al-Ḥikâyamah, yang populer dengan nama Abî Jihâd al-Mașrî. Ia termasuk salah seorang yang paling berpengaruh di kalangan kelompok-kelompok teroris dalam bidang pemikiran jihad, melalui karyanya tersebut. Pokok pemikirannya dalam mendirikan negara Islam adalah dengan tiga fase, yaitu tahap pengumpulan kekuatan dan konsolidasi serta pengacauan, tahap manajemen kekerasan dan kekejaman, dan tahap yang terakhir ekspansi berdirinya sebuah negara.
} 
pragmatis, para pencari profit dari perang, adventurism, suku-suku pragmatis hingga takfîrî sejati ${ }^{26}$ yang paling keras dalam sejarah. Sebagian orang sekuler dan agnostik yang berafiliasi dengan NIIS memandang NIIS sebagai satu-satunya kelompok bersenjata yang mampu menyerang rezim dan milisi anti-Sunnî di Suriah dan Irak, serta negara lainnya. Meski dasarnya mereka meragukan keislaman dan keberatan dengan kerusakan yang ditimbulkan oleh NIIS.

\section{Pemahaman NIIS terhadap Hadîth}

1. Hadîth tentang al-Khilâfah

Mendirikan pemerintahan dengan sistem khilâfah merupakan salah satu misi politik NIIS. Hadîth utama yang dijadikan dasar pendirian khilâfah oleh mereka adalah:

Ismấîl b. Ja'far al-Madînî bercerita kepada kami, 'Abd Allah b. Dînar bercerita kepada kami, dari Ibn 'Umar ia berkata, Rasulullah bersabda: "Setiap kalian adalah pemimpin, dan setiap pemimpin akan dimintai pertanggungjawaban atas yang dipimpinnya". ${ }^{27}$

Dalam memahami hadîth ini, NIIS menyatakan bahwa konstruksi kepemimpinan ( $r a \hat{\imath}$ ) yang dimaksud dalam hadîth tersebut-yang pemaknaannya terkait dengan QS. al-Baqarah [2]: 124 dan QS. al-Nûr [24]: 55 tentang janji Allah yang akan menyerahkan kepemimpinan kepada hambanya yang saleh_-adalah mencakup kepemimpinan politik dan agama, sehingga menjadi landasan kewajiban dan tanggung jawab mendirikan khilâfah (imâmat al-kubrâ) bagi pihak yang mampu menjalankan sharî‘ah. Mereka menafsirkan lafal kepemimpinan dengan menggunakan makna yang tidak bertentangan kepentingan agama dan politiknya. $^{28}$

Untuk menguatkan ḅujah-nya, mereka juga mengutip perkataan 'Umar b. al-Khațâab tentang keharusan mendirikan pemerintahan, "Tidak ada Islam tanpa jemaah, tidak ada jemaah tanpa imârah (kepemimpinan), dan tidak ada kepemimpinan tanpa ketaatan". ${ }^{29}$

\footnotetext{
26 Ibid., 172.

27 Abû 'Abd Allah Muḥammad b. Ismâ'il al-Bukhârî, Șaḥ̂h al-Bukhârî, Vol. 2 (Beirut:

Dâr Ibn Kathîr, 1407 H./1987 M.), 848. Muslim, Șaḥ̣̂̉ Muslim, Vol. 3, 1459.

28 Dabiq, edisi I, Ramadan 1435 H., 22.

29 Abû Muḥammad 'Abd Allah b. 'Abd al-Raḥmân al-Dârimî, Sunan al-Dârimî (Beirut:

Dâr al-Fikr, 2004), Nomor Indeks 253.
} 
Khilâfah dipahami oleh NIIS sebagai kepemimpinan yang wajib dan sah secara eksklusif karena merupakan bagian dari tradisi Ibrahim (millah Ibrâhim). Tradisi Ibrahim berarti gagasan bahwa umat Muslim harus bersatu di bawah satu kepemimpinan untuk menerapkan sharî‘ah Allah. Pada masa ini, NIIS menganggap hanya pihaknya yang paling layak mewarisi tradisi Ibrahim ini, karena telah mampu secara maksimal dalam menerapkan sharî́ah Allah. ${ }^{30}$

Berdirinya kekhilafahan NIIS secara resmi diumumkan oleh Abû Muhammad al-'Adnânî, juru bicara NIIS, pada hari pertama bulan Ramadan 1435 H. Dalam fatwa NIIS, pendirian ini sekaligus merupakan pembatal atas janji setia kepada pemimpin atau pemerintahan yang ada sebelumnya, karena pada dasarnya khilâfah global merupakan kewajiban 'ayn dan pemerintahan teritorial terbatas (lokal) hanya sementara (darurat), sehingga ketika khilâfah telah berdiri, semua umat Islam harus mengakuinya. ${ }^{31}$

Tinjauan atas pemahaman hadîth khilâfah di atas adalah bahwa pemaknaan hadîth tentang "tanggung jawab sebuah kepimpinan" dan tafsir QS. al-Nûr [24]: 55 tentang "janji Allah yang akan menyerahkan kepemimpinan kepada hamba yang saleh" merupakan upaya istidlâl yang batil, karena sebuah naș yang umum ('âm) tidak boleh digunakan atau dipelintir untuk menginterpretasi sebuah peristiwa terbatas (khâss) dan tertentu. Naiknya al-Baghdâdi sebagai khalifah NIIS terjadi setelah lebih dari 1400 tahun dari munculnya nass tersebut. ${ }^{32}$

Menanggapi konsep khilâfah NIIS, 'Alî Jum'ah, mantan Mufti Mesir, secara tegas menyatakan bahwa tidak ada satu hadîth pun yang menyeru pendirian khilâfah. Yang ada hanya hadîth "Ketika di dunia ini tidak terdapat khalifah, maka diamlah di rumahmu", dan hadîth lain mengenai larangan menyulut konflik, menciptakan fitnah, dan melahirkan perpecahan. Namun semua larangan tersebut justru dilakukan NIIS.

Deklarasi khilafah di wilayah yang mempunyai pemerintahan konstitusional itu tidak diperbolehkan dalam Islam dan tergolong pemberontakan, kecuali jika penguasa tersebut melarang didirikannya salat di wilayahnya atau kufur secara terang-terangan. Terdapat banyak

\footnotetext{
30 Dabiq, edisi I, Ramadan 1435 H., 27.

31 Dabiq, edisi X, Ramadan 1436 H., 19.

32 Lihat naskah "al-Risâlah al-Maftûhạh", yaitu surat terbuka yang ditujukan kepada Abû Bakr al-Baghdâdî dan telah ditandatangani oleh 136 ulama, 4.
} 
ayat al-Qur'ân yang menyatakan demikian sebagaimana dalam QS. alNisâ' [4]: 59 atau hadîth Nabi, "Dengar dan taatilah seorang pemimpin, meski ia adalah seorang ḥabashî yang kepalanya bagai dompol anggur". ${ }^{33}$

Ditilik dari legalitasnya, tentu saja banyak hal yang tidak dipenuhi oleh NIIS dalam mendirikan khilâfah, misalnya kontribusi dan pendapat abl al-ḥall wa al-'aqd dan konklusi mayoritas umat Islam. 'Umar pernah menyatakan "seseorang yang mendeklarasikan kepemimpinan dirinya atau orang lain tanpa bermusyawarah dengan kaum Muslim, maka tidak ada jalan lain kecuali memeranginya". "Umar tentu saja benar, karena deklarasi khilâfah atas umat Islam di seluruh dunia yang dilakukan oleh sebuah kelompok saja hanya akan menimbulkan chaos.

Seruan NIIS mengenai keharusan umat Islam di seluruh dunia untuk berada di bawah satu kepemimpinan disertai pemberian ancaman mati bagi penentangnya merupakan pemikiran yang tidak realistis dan ahistoris. Menilik sejarah kekhila fahan 'Alî, ia tidak sampai mengafirkan apalagi membunuh sebagian umat Islam yang tidak mau membaiatnya. Nadirsyah menjelaskan, sejak masa al-Khulafâ' al-Râshidûn, Bani Umayyah, dan awal masa Bani 'Abbasîyah, umat Islam sudah mempunyai kepemimpinan yang beragam, dan terjadi hingga saat ini. ${ }^{35}$

Pun Imam Nawawi memaparkan bahwa khilâfah dalam arti pemerintahan yang mengakomodir seluruh umat Islam di dunia, telah dijelaskan oleh Rasulullah, akan bertahan selama tiga puluh tahun setelah beliau wafat. Pemerintahan yang lahir setelah itu hakikatnya adalah kerajaan. $^{36}$ Kerajaan dimaksud dalam hadîth tersebut bermakna kekuasaannya bersifat lokal dan parsial yang dalam konteks saat ini formasinya dapat berbentuk negara-bangsa. ${ }^{37}$

33 al-Bukhârî, S Sậị̂ al-Bukhârî, Nomor Indeks 693.

34 al-Bukhârî, S Sậị̂ al-Bukhârî, Nomor Indeks 6830.

35 Nadirsyah Hosen, "Khilafah Islam, Fiktif!", dalam Komaruddin Hidayat (ed.), Kontroversi Khilafah (Jakarta: Mizan, 2014), 156.

36 Zakariyâ Yaḥyâ al-Nawâwî, Sharḥ Șaḥ̂ḥ Muslim, Vol. 12 (Beirut: Dâr al-Minhâj, 2002), 202. Rasulullah bersabda: "Khilafah menguasai umatku selama tiga puluh tahun, setelah itu disusul kerajaan”. Lihat Muhammad b. 'Îsâ al-Turmudhî, Sunan al-Turmudhî, Nomor Indeks 1408 (Beirut: Dâr al-Fikr, t.th).

37 Perspektif tentang formasi kepemimpinan dalam sejarah Islam amat beragam. Khadduri menglasifikasi bentuk pemerintahan Islam dalam tahap negara kota (622632), negara imperial (632-750), negara "universal" (750-900), desentralisasi (900-1500), fragmentasi (1500-1918), dan negara bangsa (1918-sekarang). Majid Khadduri, The 


\section{Hạaith tentang Jihad}

Pemahaman NIIS terhadap hadîth-ḥadîth jïhâd fî sabîl Allah dipenuhi banyak kekeliruan. Kekeliruan tersebut karena sebagian hadîth-ḥadîth yang dipahami mereka berstatus da îf dan palsu, seperti hadîth tậrîq (membunuh dengan cara membakar). Adapula status hadîthnya sahih namun penalaran terhadap hadîth tersebut tidak sesuai kerangka metodologis yang telah ditentukan oleh ulama hadîth, sebagaimana dalam kasus pemahaman bahwa jihad hanya ditafsiri perang (qitâl) terhadap pihak yang tidak sejalan dengan mereka, dan qitâl hanya dimaknai membunuh (qatl).

Kesalahan NIIS memahami hadîth jihad bisa juga dilihat dari pernyataan mereka yang mewajibkan untuk meneror seseorang dengan kewarganegaraan tertentu, Amerika dan sekutunya. Padahal motif suatu kewarganegaraan tidak pernah menjadi alasan memusuhi dalam Islam, karena warga negara tidak bertanggungjawab atas kebijakan politik pemerintahnya. Dalam al-Qur'ân Allah sudah menegaskan bahwa seseorang tidak menanggung dosa atau perbuatan orang lain. ${ }^{38}$ Begitu pula mengenai perintah untuk memerangi seseorang, meski orang tersebut telah mengucapkan dua kalimat syahadat dan tidak bersenjata. Padahal Rasulullah pernah memberikan teguran keras terhadap anak angkatnya, Usâmah b. Zayd, yang membunuh orang kafir saat mengucapkan mengucap kalimat syahadat, namun justru kepala orang kafir tersebut ditebas dengan pedangnya. ${ }^{39}$ Atas dasar hadîth tersebut, ulama menyepakati wajibnya menahan diri dari seseorang yang telah mengakui ketuhanan Allah dan kerasulan Nabi Muhammad.

Fakta di atas merupakan aturan jihad yang telah dilanggar oleh NIIS, di samping banyak syarat shar'ijihad seperti mendapatkan izin dari orang tua $^{40}$ dan hanya berjihad pada pihak yang menyerang umat Islam lebih

Islamic Law of Nations: Syaibani's Siyar (Baltimore: John Hopkins University Press, 1966), 20.

38 Lihat QS. al-An‘âm [6]: 164, QS. al-Isrâ’ [17]: 15, QS. Fâțir [35]: 18, QS. al-Zumar [39]: 7, dan QS. al-Najm [53]: 38.

39 al-Bukhârî, Șậị̂ al-Bukhârî, Nomor Indeks 3960, 4369 dan 6478. Muslim, Ṣaḥ̂h Muslim, Nomor Indeks 96.

40 al-Bukhârî, Sậị̂̂ al-Bukhârî, Nomor Indeks 3004. 
dahulu. ${ }^{41}$ Mereka juga mengabaikan etika jihad Islam yang santun yang termaktub dalam banyak hadîth ${ }^{42}$

Landasan etis jihad ini tidak dipedomani NIIS. Atas nama jihad mereka membantai puluhan ribu tawanan perang, padahal Sunnah (tradisi dan teladan) Nabi, sebagaimana ketika penaklukan kota Mekah, adalah memaafkan para tawanan. ${ }^{43}$ Mereka juga membunuh utusan negara/diplomat, relawan kemanusiaan dan reporter, yang dasarnya dalam Islam adalah diharamkan.

Praktik jihad brutal NIIS dengan aneka ragam penyiksaan seperti pembakaran, ${ }^{44}$ penguburan hidup-hidup, dan menyembelih dengan pisau merupakan praktik-praktik yang bertentangan dengan norma-norma hadîth. ${ }^{45}$ Diceritakan bahwa Rasulullah melewati seorang lelaki yang menginjakkan kakinya di paha seekor kambing dalam keadaan mengasah pisaunya, sementara kambing tersebut melihatnya. Kemudian Rasulullah menegur, "Apakah engkau bermaksud membunuhnya berkali-kali?!”, ${ }^{46}$

41 “al-Risâlah al-Maftûhah", 10.

42 Lihat misalnya Muslim, Saḅ̂h Muslim, Vol. 5, 139, Nomor Indeks 1731 dan 4619. AlTurmudhî, Sunan al-Turmudhî, Nomor Indeks 1408. Muhammad b. 'Alî al-Shawkânî, Nayl al-Awțâr, Vol. 7, Nomor Indeks 3191 (Madinah: Dâr al-Hadîth, 1413 H./1993 M). Atau Ibn Abî Shaybah, Musanaf Ibn Abî Shaybah, Vol. 6 (Kairo: al-Rushd, 1425 H./2004 M.), 498.

43 al-Bukhârî, Șạ̣ị̂ al-Bukhârî, Nomor Indeks 4332. Muslim, Șaḥ̂h Muslim, Nomor Indeks 2405.

44 Dalam melaksanakan kisas pun Nabi melarang menghukum mati dengan cara membakar, beliau bersabda: "Tidak diperbolehkan membunuh (suatu makhluk hidup) dengan api, kecuali Tuhan yang menguasai api (neraka)". Dalam hạâth lain diriwayatkan bahwa 'Alî pernah bermaksud membakar kaum yang murtad. Ketika berita itu didengar oleh Ibn 'Abbâs, ia berkata, "Aku tidak akan membakar orang-orang yang murtad, sesungguhnya Rasulullah bersabda, jangan sekali-kali kamu mengazab dengan azab Allah". Lihat Abû Dâwud, Sunan Ab̂̂u Dâmud, Vol. 11, 428. Atas dasar hadîth ini pula sebagian ulama berpendat bahwa tindakan murtad yang tidak mengandung unsur politik atau subversif tidak bisa dianggap pidana (ḅudud $)$.

45 Dalam sebuah hadîth sahih riwayat Muslim, Rasulullah bersabda: "Sesungguhnya Allah telah meletakkan kebaikan pada setiap hal, jika kalian membunuh sesuatu, maka lakukanlah dengan cara yang baik".

46 Abû 'Abd Allah Muḥammad b. 'Abd Allah al-Hâkim al-Naysâbûrî, al-Mustadrak 'alâ al-Ṣahîhayn, Nomor Indeks 7570 (Beirut: Dâr al-Kutub al-'Ilmîyah, 1990). Abû Bakr 'Abd al-Razzâq b. Himâm b. Nâfi' al-Ḥumayrî al-Yamânî al-Ṣan'ânî, al-Musannaf, Nomor Indeks 8608 (Beirut: al-Maktab al-Islâmî, 1403 H.). Aḥmad b. al-Ḥusayn b. 'Alî 
Dalam konteks ini, Rasulullah menegur dalam konteks yang sederhana, yakni saat sahabat mengasah pisau di hadapan hewan. Bagaimana dengan menyembelih dan memutilasi manusia di hadapan khalayak manusia secara umum serta disertai penghinaan?!. ${ }^{47}$

Sikap reaktif NIIS juga tidak lepas dari pengaruh hadîth-ḥadîth da îf yang ikut mewarnai rumusan konsepsi jihad mereka, seperti penyembelihan tahanan. Legitimasi mereka adalah peristiwa perang Badar saat 'Abd Allah b. Mas'ûd menyembelih 'Amr b. Hishâm Abû Jahal dan menyetorkan kepalanya kepada Rasulullah, sedangkan Rasul tidak mengingkarinya. Hadîth ini adalah hadîth yang sangat da 'îf. $^{48}$ Begitu pula yang terjadi pada Sa'ad b. Mu'ad pasca-perang Khaybar. ${ }^{49}$

Pemahaman atas hadîth "pedang" merupakan contoh lain dari kekeliruan NIIS dalam memahami hadîth, yang seakan justru membenarkan fitnah orientalis bahwa Islam disebarkan dengan pedang.

Dari perspektif penelusuran sanad, Aḥmad Karîmah, dosen universitas al-Azhar, menyatakan bahwa hadith diutusnya Nabi menjelang hari kiamat dengan menggunakan pedang tidak sahih penisbahanya. Semua jalur sanadnya mengandung 'illat dan hadîthnya da' îf. 'Abd al-Raḥmân b. Thâbit b. Thawbân sebagai salah satu rawinya diragukan kredibilitasnya oleh para kritikus hadîth. Mengutip Imam

b. Mûsâ al-Bayhaqî, al-Sunan al-Kubrâ, Nomor Indeks 1941 (Beirut: Dâr al-Kutub al'Ilmîyah, 2008).

47 Dalam hadîth lain riwayat Imam Muslim dinyatakan, Rasulullah bersabda: "Barangsiapa mengacungkan senjata tajam kepada saudaranya (Muslim) maka malaikat akan melaknatnya hingga ia berhenti".

48 Seluruh riwayat yang menyatakan bahwa dihaturkan kepada Rasulullah sebagian kepala musuhnya, seperti kepala Ka‘b b. al-Ashrâf, al-Aswad al-'Unsî, Rifâ'ah b. Qays, dan Abû Jahal oleh Ibn Mas'ûd pada perang badar, adalah da'îf. Tidak ada satu pun riwayat yang dapat dipercaya, yang ada hanya pembunuhan saja. Lihat Abû Dâwud alSijistânî, al-Marâsîl ma'a al-Asânîd (Damaskus: Dâr al-Qalam, 1406 H./1986 M.), 328. Saî̀d b. Manșûr, Sunan Saî̀d b. Manșûr (Saudi Arabia: Dâr al-Ṣumaîî, 1414 H.), Nomor Indeks 2651. Namun sebuah riwayat menyatakan, pernah ada seorang sahabat yang menyembelih musuhnya dan menghaturkan kepalanya kepada Abû Bakr dan spontan Abû Bakr marah dan mengingkarinya. Lihat Ahamad b. Shu'ayb al-Nasấî, al-Sunan alKubrâ, Nomor Indeks 8620 (t.t: Muassasat al-Risâlah, 2001). Al-Bayhaqî, al-Sunan alKubrâ, Vol. 9, 132.

49 'Abd al-Mâlik b. Hishâm b. Ayyûb al-Ḥumayrî, al-Sîrah al-Nabanryyah (Madinah: Mu'asasah 'Ulûm al-Qur'ân, t.th.), 87. 
Ahmad, Karîmah menyatakan bahwa hadîth-ḥadîthnya adalah munkar, dan di antaranya adalah hadîth "pedang" ini.

Dengan demikian, menggunakan hadîth tersebut sebagai dasar kewajiban seorang Muslim membunuh non-Muslim, memerangi nonMuslim yang tidak menyerang (pasif), dan menjadikan ideologi "pedang" sebagai dasar ajaran Islam merupakan suatu kekeliruan yang fatal. Hukum Islam yang mendasar (ușîl) hanya dapat ditetapkan melalui dalil yang dipastikan validitas (qat'î al-wurûd) dan maknanya (qat'î al-dilâlab), bukan melalui praduga (zannî al-dilâlah) atau dalil yang lemah.

Lafal pedang (sayf) dalam hadîth tersebut di atas mempunyai dua kemungkinan makna, ofensif dan defensif. Makna hadîth tersebut adalah bahwa seorang manusia tidak diperkenankan melakukan upaya penbunuhan kecuali dalam keadaan pembelaan (noodweer) atau terpaksa, yaitu mempertahankan diri dan mengeksekusi hukuman pidana dengan cara-cara yang baik. Kekeliruan paham terkait berjihad terhadap orang kafir adalah implikasi dari kelalaian mereka terhadap kaidah bahwa hadith adalah interpreter al-Qur'ân, sedangkan al-Qur'ân telah berkali-kali menegaskan jaminan kebebasan memilih agama.

Mengenai hadith yang berisi perintah untuk memerangi seseorang hingga bersaksi bahwa tiada Tuhan selain Allah dan seterusnya, ini adalah hạâth sahih. Oleh NIIS hadîth ini dipahami dengan kaca pandang mereka sendiri. Hadîth ini telah mengiringi transmisi sejarah berbagai generasi dan tidak tidak pernah dimaknai sebagai legitimasi umat Islam untuk membunuh non-Muslim yang pasif. Ini karena hadîth tersebut dipahami sesuai dengan aturan bahasa Arab yang berlaku.

Redaksi hadîth berupa saling membunuh (uqâtil) bukan untuk membunuh (aqtul), keduanya mempunyai perbedaan petunjuk makna yang cukup signifikan, karena lafal yang pertama menunjukkan adanya keterlibatan dua pihak (mufa'alah/mushârakah). Pihak yang memulai disebut pembunuh (qâtil) dan pihak yang mempertahankan diri disebut penahan (muqâtil). Dengan demikian, mayoritas ulama menyatakan bahwa pembunuhan atas orang yang meninggalkan salat dan zakat bukan bergantung pada perbuatan itu saja, melainkan jika disertai dengan 
pembangkangan. Pendapat ini dinyakan oleh Ibn Hajar ${ }^{50}$ dan Imam alShâfi î. ${ }^{51}$

3. Hadîth tentang Hijrah

NIIS menganggap hijrah, meninggalkan dâr al-kufr menuju dâr alIslâm ${ }^{52}$, merupakan salah satu pilar penting Islam. Karena itu hukumnya adalah wajib sebagai dukungan atas jihad dan merupakan media pengampunan dosa.$^{53}$ NIIS mengutip beberapa ḥadîth di bawah ini:

'Abd Allah bercerita kepada kami, ayahku bercerita kepada saya, Hajjâj bercerita kepada kami, Layth bercerita kepada kami, ia berkata, Yazîd b. Abî Habî̉b bercerita kepada saya, dari Abû al-Khayr, bahwa Junâdah b. Abî Umayyah bercerita kepadanya, bahwa sekolompok lelaki dari sahabat Rasulullah sebagian menyeru bahwa hijrah telah terhenti. Lalu mereka berselisih dan mencari kejelasan kepada Rasulullah, saya berkata, "Wahai Rasulullah, beberapa orang mengatakan bahwa hijrah telah terhenti”, Rasulullah menjawab: "Hijrah tidak akan terhenti selama jihad masih berlaku". ${ }^{54}$

Ishâq b. 'Îsâ bercerita kepada kami, Yahyâ b. Hamzah bercerita kepada kami, dari 'Ațâ' al-Khurasânî, Ibn Muhayrîz bercerita kepada saya, dari 'Abd Allah al-Sa'dî, dari seorang lelaki Banî Mâlik b. Hanbal, bahwa ia datang kepada Nabi yang tengah berada di antara sahabatnya ... Nabi bersabda: "Engkau lebih membutuhkan dibanding mereka. Hijrah tidak akan terputus selama musuh terus diperangi". ${ }^{5}$

Hijrah merupakan salah satu ajaran prioritas NIIS. Kewajiban hijrah diperuntukkan bagi setiap Muslim, baik laki-laki maupun perempuan, dari negara mereka yang kafir menuju negara Islam. Kewajiban dalam hal ini termasuk dalam kategori fard 'ayn, yakni untuk semua umat Muslim. Kewajiban hijrah ini sama dengan kewajiban salat, puasa dan zakat, sehingga kegiatan seperti belajar-mengajar tidak dapat menggugurkan

50 Ibn Ḥajar al-'Asqalânî, Fatḥ al-Bâri, Vol. 1 (Beirut: Dâr al-Rayyân li al-Turâth, 1407 H./1986 M.), 59 .

51 Ibid.

${ }^{52}$ Dabiq, edisi VIII, Jumâdâ al-Akhîrah 1436 H., 32.

53 Dabiq, edisi III, Syawal 1435 H., 23.

54 Aḥmad b. Hanbal, Musnad Aḥmad, Nomor Indeks 23079 (Jedah: Dâr al-Minhâj, 1429 H.,/2008 M), 62.

55 Ibid., Nomor Indeks 21819. 
kewajiban ini. ${ }^{56}$ Sebaliknya, meninggalkan hijrah dan kembali menuju Dâr al-Kufr merupakan dosa besar yang bisa berujung pada kemurtadan. ${ }^{57}$

Dalam hal hadîth seruan hijrah di atas, NIIS memahami sebuah hạaith tanpa menimbang keberadaan hạdîth lain, seperti yang menyatakan bahwa, sesungguhnya aktivitas hijrah telah terhenti pascapenaklukan kota Makkah. Nabi bersabda:

Âdam b. Abî Iyâs bercerita kepada kami, Shaybân bercerita kepada kami, dari Manșûr, dari Mujâhid, dari Tâwus, dari Ibn 'Abbâs, ia berkata, Rasulullah bersabda setelah penaklukan kota Makkah, "Tidak ada hijrah lagi, yang ada adalah jihad dan niat. Jika kalian ditugaskan berangkat jihad, maka berangkatlah". ${ }^{58}$

Keterdesakan menjadi kata kunci hijrah dalam Islam, sebuah hadîth riwayat Abû Sa'îd al-Khudrî membuktikan bahwa seorang badui bertanya kepada Nabi tentang hijrah. Nabi kemudian bersabda, "Celaka engkau, urusan hijrah amatlah berat. Jika engkau mempunyai aktivitas ternak unta sehingga dapat engkau sedekahkan sebagian hasilnya, maka lakukanlah. Allah tidak akan mengurangi pahalamu sedikit pun". ${ }^{59}$ Ini menunjukkan bahwa hijrah tidaklah ringan. Beramal baik di mana pun akan dibalas oleh Allah, dengan niat yang baik. Al-Khatâ̂bî memaknai hạâith tersebut dan menyatakan bahwa maksudnya adalah, dengan niat yang baik, engkau bisa saja mendapatkan pahala hijrah, meskipun tinggal di tepi pantai atau tinggal di tempat terpencil. ${ }^{60}$ Sebagian ulama menyatakan bahwa selama kaum Muslim dapat menjalankan ibadah secara aman, maka tidak diwajibkan hijrah atas mereka. Abû Zahrah mengutip pendapat Abû Hanifah menulis bahwa tolok ukur penentuan dâr al-Islam adalah jika seorang Muslim hidup aman di dalamnya. ${ }^{61}$

4. Hadîth tentang Iman

NIIS mempunyai konsep iman yang sangat ekstrem. Mereka berpandangan bahwa seseorang yang hanya mengucapkan kalimat

${ }^{56}$ Dabiq, edisi III, Syawal 1435 H., 26.

${ }^{57}$ Dabiq, edisi XI, Zulqa'dah 1426 H., 23.

58 al-Bukhârî, Șahîh al-Bukhârî, Nomor Indeks 2912. Muslim, Saḥ̂ḥ Muslim, Nomor Indeks 1353.

59 al-Bukhârî, Sahîh al-Bukhârî, Nomor Indeks 1452. Muslim, Sahị̣̂ Muslim, Nomor Indeks 1865.

60 Abû Sulaymân al-Khatââi, Ma'âlim al-Sunan, Vol. 2 (Aleppo: al-Maṭba'ah al-'Ilmîyah, 1351 H./1932 M.), 233.

61 Ibid., 38. 
syahadat saja belum bisa disebut beriman. Seseorang yang masih percaya dan patuh pada peraturan, sistem, dan perundang-undangan selain yang datang dari Allah dianggap menyekutukan Allah (syirik). ${ }^{62}$ Begitupula kafir, orang luar kelompok, yang mereka sebut Murji'ah atau penganut irjâ ${ }^{\text {63 }}$, di mana salah satu cirinya adalah ketaktaatan secara kâffah dalam bentuk amal seperti jihad, di samping ikrar iman lisannya. Dengan konsep yang demikian, NIIS bisa disebut sebagai bagian dari kelompok takfîrî paling fanatik sepanjang sejarah. ${ }^{64}$

Kepercayaan mereka yang demikian dilandasi oleh pemahaman atas beberapa hadîth, di samping ayat-ayat al-Qur'ân. ${ }^{65}$ Ḥadîth-ḥadîth dimaksud adalah sebagai berikut:

'Abd Allah b. Muhammad al-Musnidî bercerita kepada saya, ia berkata, Abû Rawh al-Ḥaramî b. 'Imârah bercerita kepada saya, ia berkata, Shu'bah bercerita kepada saya, dari Wâqid b. Muhammad, ia berkata, saya mendengar ayah saya meriwayatkan hadîth dari Ibn 'Umar, bahwa Rasulullah bersabda: "Aku diperintah untuk memerangi manusia hingga mereka bersaksi bahwa tiada Tuhan selain Allah dan Muhammad adalah Rasulullah, mendirikan salat, dan menunaikan zakat. Jika mereka

62 Dabiq, edisi II, Ramadhan 1435 H., 10.

63 Dabiq, edisi VIII, Jumâdâ al-Akhîrah 1436 H., 43-44. Dalam kategori Irjấ ini ISIS memasukkan banyak aliran teologi di dalamnya, seperti Ash'arîyah, Mâturidîyah, dan Jahmîyah. Lihat Dabiq, edisi X, Ramadan 1436 H., 55. ISIS bukan hanya sekali ini menggelari ulama dan mayoritas umat Islam sebagai Murji'ah, namun setiap kali mendapati praktik yang dianggap terlalu lentur dalam beragama. Kegemaran menggunakan istilah tersebut sudah dimulai sejak ideolog mereka menulis kitab Imtâ' alNażarî fî Kashf Shubuhât Murjïat al-'Așr.

64 Dalam sejarah Islam telah dikenal kelompok yang mempunyai ideologi ekstrem dan amat ceroboh dalam mengafirkan sesama umat Islam, yaitu Khawârij. Kelompok ini sudah mempunyai benih sejak masa Nabi, yaitu dalam diri Dhû Khuwayṣirah alias Ḥirquṣ b. Zuhayr al-Tamîmî, dan mulai mencuat dalam melakukan pemberontakan pada masa Ali b. Abi Tâlib. Gerakan Wahabi juga mempunyai pola serupa dengan Khawârij dan secara mayoritas diadopsi oleh ISIS, walaupun ISIS menolak disebut Khawârij. Radikalisme Khawârij dan Wahabi tidak sendirian diadopsi oleh ISIS, tapi juga oleh Taliban dan al-Qaeda, namun ISIS adalah yang paling keras di antara mereka. ISIS bahkan tegas mengafirkan Taliban dan al-Qaida. Lihat serial artikel berjudul "Sekutu al-Qaida di Syam".

${ }^{65}$ QS. al-Bayyinah [98]: 5, QS. al-Tawbah [9]: 5 dan 11, dan QS. Al 'Imrân [3]: 32. 
melakukannya, maka darah dan harta mereka telah terjaga dariku kecuali atas hak Islam dan perhitungan hisabnya ada pada Allah". ${ }^{66}$

Penyebutan syahadat dan empat perkara lain berupa salat, zakat, puasa, dan haji secara bersamaan dalam satu hadîth menjadi dasar bagi NIIS untuk mengklaim bahwa seseorang yang telah mengucapkan kalimat syahadat, namun meninggalkan atau tidak melaksanakan salah satu dari keempat perkara lainnya tersebut adalah kufur. Meskipun ia mengakui kewajibannya, tapi menurut NIIS halal untuk membunuhnya merujuk perintah Nabi untuk membunuh. ${ }^{67}$ Mempraktikkan sebagian hukum Islam dianggap tidak mampu menyelamatkan seseorang dari kekufuran, bahkan jika hal tersebut disebabkan oleh kebodohan. ${ }^{68}$

Dengan kualifikasi iman yang demikian, tidak ayal lagi jika NIIS mempunyai kesimpulan tentang kondisi umat Islam bahwa mayoritas umat Islam pada umumnya terjembab pada kekufuran dan murtad. ${ }^{69}$

Pemahaman NIIS tentang ḥadîth-ḥadîth keimanan tersebut bertentangan dengan prinsip Islam bahwa, seseorang yang telah mengakui keesaan Allah dan kerasulan Muhammad adalah seorang mukmin, sehingga tidak dapat dikafirkan. Adapun kelalaian amal fisik tidak dapat membatalkan keimanan yang ada di hati sebagaimana dinyatakan Allah QS. al-Nisâ’ [4]: 94. Rasulullah juga bersabda:

Saî̀d b. Manșûr bercerita kepada kami, Abû Mu'âwîyah bercerita kepada kami, Ja'far b. Barqân bercerita kepada kami, dari Yazîd b. Abî Nashbah, dari Anas b. Mâlik, ia berkata, Rasulullah bersabda, "Termasuk tiga pokok iman adalah menahan diri dari seseorang yang telah mengakui keesaan Allah, kita tidak diperbolehkan mengafirkannya sebab suatu dosa, dan tidak mengeluarkannya dari Islam sebab sebuah perbuatan. ${ }^{70}$

Abû al-Yamân bercerita kepada kami, Shu'ayb bercerita kepada kami, dari al-Zuhrî, Saî̀ b. al-Musayyab bercerita kepada kami, bahwa Abû Hurayrah berkata, Rasulullah bersabda, "Seseorang yang telah mengakui keesaan Allah, maka aku menjamin keselamatan jiwa dan hartanya, kecuali yang berkaitan dengan hak pribadinya, dan hisabnya ada di tangan Allah. ${ }^{71}$

66 al-Bukhârî, Ṣaḥ̂ḥ al-Bukhârî, Nomor Indeks 25. Muslim, Ṣậị̂ Muslim, Nomor Indeks 22.

${ }^{67}$ Dabiq, edisi VIII, Jumâdâ al-Akhirah 1436 H., 43-44.

68 Ibid., 44.

69 Ibid., 39.

70 Abû Dâwud, Sunan Abû Dâmud, Nomor Indeks 2532.

71 al-Bukhârî, Șahîh al-Bukhârî, Nomor Indeks 2946. 
Dalam hal iman, Islam menglasifikasi hal-hal yang bersifat akidah (i'tiqâdiyâh) dan bagian/cabang (al-fur $\hat{u}^{\prime}$ ), tidak sebagaimana NIIS yang menjadikan rancu antara domain hati (qalbi) dan amaliah. Mereka bahkan memasukkan hal-hal yang termasuk akhlak ke dalam akidah, sehingga ketika ada satu aspek kehidupan dari seseorang yang tidak islami. Mereka akan menjadikan hal tersebut sebagai penodaan atas akidah (kufur).

Menghukumi seseorang dengan kafir dalam Islam mempunyai prasyarat yang sangat ketat ${ }^{72}$ dan mempunyai risiko yang serius seperti dalam hal batalnya perkawinan, waris, dan lain sebagainya. Apalagi jika yang dikafirkan adalah sebuah pemerintahan. Sayangnya, ideologi takfìr sudah menjadi substansi ajaran NIIS dalam bidang keimanan. Keyakinan bahwa praktik Islam yang tidak kâffah adalah bentuk kekafiran menjadi landasan teologis mereka. Melalui proses takfîr, mereka menghalalkan darah umat Islam yang telah diklaim kafir; kehidupan, kehormatan, harta, dan hak-hak mereka boleh dirampas. Ini merupakan warisan tradisi Khawârij, yang sebagimana dinyatakan oleh Ibn Taymîyah bahwa inti keberagamaan mereka adalah menyalahi mayoritas umat Islam dan menghalalkan darah dan harta mereka. ${ }^{73}$ Padahal mengalirkan darah seorang yang beriman dalam Islam merupakan pidana yang sangat serius dan diancam hukuman berat.

Terkait keimanan dan takfîr, NIIS juga mempunyai pandangan bahwa menjalin hubungan diplomatik, bersekutu, bekerjasama, dan meminta tolong kepada orang kafir merupakan bentuk kekafiran. Padahal jika ditilik dalam Sunnah, Nabi telah meminta tolong kepada 'Abd Allah b. Urayqat yang musyrik dalam proses hijrahnya. 'Abd Allah menjadi penunjuk jalan bagi Nabi hingga mencapai kota Madinah. Begitu pula 'Umar, pasca-penaklukannya atas Persia dan Romawi, ia mempekerjakan penduduk lokal yang musyrik sebagai juru tulis. 'Umar juga mengadopsi sistem administrasi mereka. ${ }^{74}$ Dengan demikian, hakikatnya Islam tidak

\footnotetext{
72 Terkait menghukumi seseorang dengan kafir, paling tidak terdapat di antaranya ketentuan berikut: tidak diperkenankan mengafirkan karena masalah khilâfîyah, dilarang mengafirkan sebuah kelompok secara general, tidak boleh mengafirkan tanpa klarifikasi, tidak boleh mengafirkan kecuali atas dasar penyebab yang disepakati kekufurannya, dan lain sebagainya.

73 Ibn Taymîyah, Majmû al-Fatâwâ, Vol. 13 (Madinah: Mujamma‘ al-Malik Fahd, 1425 H./2004 M.), 209.

${ }^{74}$ Jâd al-Ḥaqq 'Alî Jâd al-Haqq, Naq̣̣ al-Farîdah al-Ghâibah (Kairo: t.p., 1414 H.), 46.
} 
menutup kemungkinan kerjasama dengan siapa pun, selama tidak melanggar nașs șarị̂ atau ijmấ:

\section{Hadîth tentang al-Malhamat al-Kubrâ}

Hadîth-hadîth futuristik tentang akan terjadinya pertempuran besar (al-malhamat al-kubrâ) yang akan menjadi penanda akhir kehidupan dunia menjadi komoditas politik yang penting bagi NIIS. Mereka berusaha melakukan propaganda menggunakan hadîth-ḥadîth akhir zaman ini untuk menarik simpati dan dukungan dari umat Islam. Padahal yang mereka lakukan, sebagaimana dalam kasus menarik Barat ke dalam pertempuran darat, sesungguhnya adalah usaha hipokratis untuk mendapatkan pengakuan bahwa mereka adalah kelompok yang akan dimenangkan (al-tâifah al-mansûurah). Ulama al-Azhar secara tegas menyatakan, bahwa tidak terdapat satu pun hadîth yang menyebutkan secara pasti kapan dunia akan berakhir, begitu pula tentang usia dunia saat ini, jika pun ada itu adalah isrấiliyât atau hadîth-ḥadîth da 'îf..$^{75}$

Melalui hadîth-ḥadîth ini, NIIS juga berusaha menggiring opini publik untuk membenarkan upaya mereka mendirikan sebuah negara dan mempersenjatai para milisi. Mereka menyatakan bahwa mereka adalah generasi ketiga yang akan menaklukkan Kostantinopel (Istanbul) dan Romawi. Mereka mengaburkan fakta sejarah bahwa Konstantinopel telah ditaklukan sebelumnya, dan Romawi juga telah ditaklukkan sejak masa Rasulullah.

Dalam propagandanya, mereka juga berusaha mencocokan janji hadîth dengan fakta yang terjadi hari ini, yakni bergabungnya ratusan orang dari Barat ke dalam NIIS, kembalinya perbudakan, dan terbentuknya koalisi internasional untuk memerangi NIIS. Mereka mengabaikan kenyataan, bahwa yang menjadikan masyarakat internasional bergerak menumpas mereka adalah karena kejahatan kemanusiaan mereka terhadap umat Islam dan warga-warga dunia.

Hadîth yang secara keliru dipahami oleh NIIS dalam hal ini, di antaranya adalah pernyataan Nabi bahwa kekuasaan umatnya akan mencapai sisi Timur dan barat dunia ${ }^{76}$, yang tidak pernah terjadi, karena ada wilayah yang belum pernah ditaklukkan Umat Islam sampai saat ini.

\footnotetext{
75 http:/ / www.al-madina.com/node/608689?risala. Diakses pada 15 Juni 2016.

${ }^{76}$ Muslim, Sahîh Muslim, Nomor Indeks 7440.
} 
Mereka merasa menjadi pihak yang mendapatkan tugas untuk merealisir janji tersebut.

Mestinya NIIS memahami, bahwa salah satu pola ungkapan (ta'bîr) dalam bahasa Arab adalah menggambarkan sesuatu yang kecil dengan sesuatu yang besar karena urgensinya, begitu pula sesuatu yang sedikit dengan sesuatu yang banyak. Dengan demikian, hadith tersebut bisa dipahami menunjukkan luasnya wilayah teritorial yang dimiliki oleh umat Islam, dan ini telah terjadi saat kaum Muslim yang hidup di kawasan Jazirah Arab telah sampai kekuasaannya ke Cina di Timur dan Benua Atlantik di Barat. ${ }^{77}$ Dhû al-Qarnayn yang diceritakan oleh al-Qur'ân bahwa ia telah sampai ke tempat terbit dan tenggelamnya matahari bukan berarti ia sampai ke Jepang di Timur dan Amerika di Barat, tetapi yang dikehendaki adalah luasnya wilayah kekuasaannya. ${ }^{78}$

Hadîth tersebut juga bisa dipahami secara maknawi, karena secara nyata agama Islam telah mencapai dakwahnya ke seluruh penjuru bumi dan telah dikaji di berbagai universitas, serta nilai-nilai ajarannya telah tersebar, hingga turut serta mempengaruhi formasi berbagai budaya dan peradaban negara.

\section{Catatan Akhir}

Pemahaman NIIS terhadap hạîth Nabi mengalami banyak ketidaksesuaian dengan metodologi pemahaman hadîth yang menjadi pedoman mayoritas ulama hadîth, seperti dalam hal proses validasi, mempertimbangan maqâsid al-sharîah, mengomparasikan satu teks hadîth dengan hadîth lain, mendiskusikan aspek asbâb al-wurûd, serta mengaplikasikan petunjuk tata bahasa Arab dalam menentukan madlûl alb̧adith. Pemahaman NIIS yang menyeleweng tersebut kerap berlatar politis dan bersifat hipokrit. Retorika tentang arah pemaknaan hadîth seringkali menjadi alat klaim untuk memperjuangkan propagandapropaganda politiknya.

Mayoritas ulama di seluruh dunia, utamanya yang moderat, dalam kebanyakan kasus, menolak kritik NIIS terhadap hadîth Nabi, karena di samping banyak menggunakan hạaith da îf, bahkan mawdû, dalam ḥujjahnya, mereka juga mempunyai kekeliruan metodologis yang fatal, sehingga

77 'Aṭ̂yah Șaqar, Naqd al-Farịdah al-Ghâibah (Kairo: t.p., 1414 H.), 76.

${ }^{78}$ Ibid. 
tidak memiliki akar teologis, ideologis, dan historis yang kuat, sahih dan otoritatif.

\section{Daftar Rujukan}

'Asqalânî (al), Ibn Hajar. Fatḥ al-Bâri, Vol. 1. Beirut: Dâr al-Rayyân li alTurâth, 1407 H./1986 M.

Azami, M. M. Hadis Nabi dan Sejarah Kodifikasinya, terj. Ali Mustafa Yaqub. Jakarta: Pustaka Firdaus, 2009.

Bayhaqî (al), Aḥmad b. al-Ḥusayn b. 'Alî b. Mûsâ. al-Sunan al-Kubrâ, Nomor Indeks 1941. Beirut: Dâr al-Kutub al-'Ilmîyah, 2008.

Bukhârî (al), Abû 'Abd Allah Muhammad b. Ismâ'il. Șahîh al-Bukhârî, Vol. 2. Beirut: Dâr Ibn Kathîr, 1407 H./1987 M.

Dârimî (al), Abû Muhammad 'Abd Allah b. 'Abd al-Raḥmân. Sunan alDârimî. Beirut: Dâr al-Fikr, 2004.

Dhahabî (al), Muḥammad Ḥusayn. al-Tafsîr wa al-Mufasirûn, Vol. 1. Mesir: Maktabah Wahbah, 2000.

Felter, Joseph dan Fishman, Brian. al-Qa'ida's Foreign Fighters in Iraq. New York: Combating Terrorism Center, 2007.

Gelfand, Lauren. "al-Qaeda in Iraq Regroups and Names New Leadership”, dalam Janes's Defense Weekly, 19 Mei 2010.

Gove, Philip Babcock et. al. Webster Third New International Dictionary of

The English Language. Massachusett: G \& C Merriam Company, 1961. Gulmohamad, Zana Khasraw. "The Rise and Fall of The Islamic State of Iraq and al-Sham (Levant) ISIS", Global Security Studies, Vol. 5, Spring, 2014.

Hanbal, Aḥmad b. Musnad Aḥmad, Nomor Indeks 23079. Jedah: Dâr alMinhâj, 1429 H.,/2008 M

Haqq (al), Jâd al-Haqq 'Alî Jâd. Naqd al-Farị̂ah al-Ghâibah. Kairo: t.p., $1414 \mathrm{H}$.

Ḥumayrî (al), 'Abd al-Mâlik b. Hishâm b. Ayyûb. al-Sîrah al-Nabawîyah. Madinah: Mu'asasah 'Ulûm al-Qur'ân, t.th.

Halim, Abd. Relasi Islam Politik dan Kekuasaan. Yogyakarta: LKiS, 2013. Hasan, Noorhaidi. "Book Review: Islam Politik Teori Gerakan Sosial dan Pencarian Model Pengkajian Islam Baru Lintas-Disiplin", alJâmi'ah, Vol. 44, No. 1, 2006.

Hosen, Nadirsyah. "Khilafah Islam, Fiktif!”, dalam Komaruddin Hidayat (ed.), Kontroversi Khilafah. Jakarta: Mizan, 2014. 
Ibrâhîm, Fuâd. Dâ'ish min al-Najdi ilâ al-Baghdâdî. Beirut: al-Markaz alAwwal li al-Dirâsât wa al-Tawthîq, 2015.

Khadduri, Majid. The Islamic Law of Nations: Syaibani's Siyar. Baltimore: John Hopkins University Press, 1966.

Khatâ̂bî (al), Abû Sulaymân. Ma'âlim al-Sunan, Vol. 2. Aleppo: alMațba'ah al-'Ilmîyah, 1351 H./1932 M.

Khâtîb (al), Muhammad 'Ajjâj. al-Sunnah Qabl al-Tadwîn. Beirut: Dâr alFikr, 1997.

-----. Ușul al-Ḥadîth 'Ulûmuh wa Muṣtalaḥuh. Beirut: Dâr al-Fikr, 1989.

Ma'arif, Ahmad Syafi'i. Islam dan Masalab Kenegaraan. Jakarta: LP3ES, 1985.

Manșûr, Sa î̀d b. Sunan Sa îd b. Manșûr. Saudi Arabia: Dâr al-Ṣumai'î, 1414 $\mathrm{H}$.

Majalah "Dabiq" edisi I sampai dengan XII, Ramadhan 1435 H-Safar $1437 \mathrm{H}$.

Marwazî (al), Muhạmmad b. Nașr. al-Sunnah. Beirut: Maktabat al-Dâr, $1406 \mathrm{H}$.

Mashuri, Ikhwanul Kiram. ISIS Jihad atau Petualangan. Jakarta: Republika, 2014.

Mbai, Anshaad. Dinamika Baru Jejaring Teror di Indonesia. Jakarta: AS Production, 2014.

Muhammad, Reno. ISIS Kebiadaban Konspirasi Global. Jakarta: Noura Books, 2014.

Napoleoni, Loretta. Insurgent Iraq al-Zarqawi and The New Generation. New York: Seven Stories Press, 2005.

Nasấî (al), Ahamad b. Shu'ayb. al-Sunan al-Kubrâ, Nomor Indeks 8620. t.t: Muassasat al-Risâlah, 2001.

Nawâwî (al), Zakariyâ Yaḥyâ. Sharḥ Ṣahîh Muslim, Vol. 12. Beirut: Dâr alMinhâj, 2002.

Naysâbûrî (al), Abû 'Abd Allah Muhammad b. 'Abd Allah al-Hâkim. alMustadrak 'alâ al-Sabîhayn, Nomor Indeks 7570. Beirut: Dâr al-Kutub al-'Ilmîyah, 1990.

Naysabûrî (al), Abû al-Ḥusayn Muslim b. al-Hajajâj. Șaḥ̂ḥ Muslim, Vol. 3. Beirut: Dâr Ihyâ al-Turâth al-'Arabî, t.th.

Qushayrî (al), Abû al-Husayn Muslim b. al-Hajjầj. Șaḅ̂h Muslim, Vol. 1. Beirut: Dâr al-Fikr, 1993. 
Richardson, Louise. What Terrorism Want: Understanding the Terrorist Threat. USA: Random House, 2006.

Șan'ânî (al), Abû Bakr 'Abd al-Razzâq b. Himâm b. Nâfi' al-Humayrî alYamânî. al-Musannaf, Nomor Indeks 8608. Beirut: al-Maktab alIslâmî, $1403 \mathrm{H}$.

Ṣaqar, 'Ațîyah. Naqd al-Farịdah al-Ghâibah. Kairo: t.p., 1414 H.

Shawkânî, Muhammad b. 'Alî. Nayl al-Awtâr, Vol. 7, Nomor Indeks 3191. Madinah: Dâr al-Hadîth, 1413 H./1993 M.

Shaybah, Ibn Abî. Mușanaf Ibn Abî Shaybah, Vol. 6. Kairo: al-Rushd, 1425 H./2004 M.

Sijistânî (al), Abû Dâwud. al-Marâsîl ma'a al-Asânîd. Damaskus: Dâr alQalam, 1406 H./1986 M.

Taymîyah, Ibn. Majmû́ al-Fatâwâ, Vol. 13. Madinah: Mujamma‘ al-Malik Fahd, 1425 H./2004 M.

Turmudhî (al), Muhammad b. 'Îsâ. Sunan al-Turmudhî, Nomor Indeks 1408. Beirut: Dâr al-Fikr, t.th.

Weiss, Michael dan Hassan, Hassan. ISIS: The Inside Story, terj. Tri Wibowo BS. Jakarta: Prenada Media, 2015. 